\title{
Democratic definitely, parochial possibly, challenged certainly: the College at the century's end'
}

\author{
Anthony W. Clare
}

Whatever else, the Royal College of Psychiatrists is a democratic organisation. From its internal committee structure with its plethora of representatives from every sectional interest, speciality, sub-speciality, division, region and country, to the regularity, detail and care with which it consults its membership. from the President, Dean, Court of Electors and Council to the modest sub-committee and working party. the College rests on the principle that every psychiatrist possessing MRCPsych is a full and equal member of the profession and the ballot box is supreme. This, it is important to remember, has not been true of every medical Royal College since inception and it is still only true of some of them. But it is hardly surprising given the origins of the Royal College of Psychiatrists. Some idea of the ferment of the time can be found in the report of the debate held at the quarterly meeting of the Royal Medico-Psychological Association in November 1963 and published a special supplement of the British Journal of Psychiatry the following year, 1964. The academic psychiatrists of the time favoured closer links with the Royal College of Physicians. Those pushing for a college of psychiatrists were, for the most part, psychiatrists working in the large mental hospitals of the time who feared they would be neglected and frozen out from power and influence. From its very beginnings, as I know personally, the College struggled to avoid being a club, a small, unrepresentable clique, self-satisfied and self-preoccupied. Its ability to convert and absorb its critics is one of its more engaging qualities.

At its inception in 1971, it elected as its President not one of the many senior asylumbased psychiatrists who had fought long and hard for the cause but an academic, Professor (later Sir) Martin Roth, who while not one of the

'See accompanying paper pp. 11-15, this issue. opponents of the idea of a College had come late to the cause. Since then, academics have dominated the presidency and senior officer positions. Confronted by a militant group of trainees (the Association of Trainees in Psychiatry - APIT), highly critical of what it saw as an exaggerated emphasis on a membership examination to the neglect of accreditation and training, the College invited one of its representatives, me as it happens, to address its inaugural meeting. I still remember, with some embarrassment, President Roth having to wait, while I abreacted trainee woes in front of a distinguished and largely uncomprehending invited audience. Within a few years, the College's Collegiate Training Committee had largely replaced APIT and not too many years later again, one of the most fervent and articulate of its leaders, the late and much respected John Hamilton, had himself become a senior and highly influential College officer.

In such a context, a Gallup poll-type exercise such as the questionnaire sent to a large random sample of the College's membership is characteristic of the College's fear of becoming introspective and unrepresentative and its desire to know just what members think of what Belgrave Square is doing in their name. The findings are reported with characteristic caution. An overall response rate of $63 \%$ is described as 'comparatively low', although for this kind of exercise that is a somewhat humble description. For the most part, the findings are predictable. The British Journal of Psychiatry is rightly valued - it is a highly professional journal. Nearly two in five respondents have never visited the College headquarters. Most respondents feel the College's public education activities to be important but not as effective as they would wish and respondents judge the raising of standards of education and training as the College's most important achievement since its foundation - which will bring a justifiable smile of quiet satisfaction to those who fought so long and hard at the time of the College's creation and inception to ensure 
that education and training should be its raison d'être.

The fact that so many indict the College for not trying hard enough or for failing to influence the policies of the Department of Health may owe more to the changes that have happened to psychiatry in the years since the College's formation than to anything the College has or has not done. Since 1971 the institutional base of psychiatry has been eroded by the run-down of the psychiatric hospitals. Whereas formerly, psychiatrists were unchallenged leaders in their own mental hospitals, now the process known as community psychiatry has drawn them into uncharted waters. Where once it was the psychiatrist's voice that spoke on matters psychiatric and psychological, now there is a veritable clamour in which the competing voices of psychologist, social worker, occupational therapist, general practitioner and nurse, not to mention administrator, can be heard laying claim to manage various forms of psychiatric disorder and challenging the expertise of the psychiatrist. Whether the College could or indeed should have done much to influence or shape this trend is arguable but some, such as the Lancet in a polemical article in 1985 (Anonymous, 1985), clearly feel it should:

Much of the progress made by psychiatry in the past generation has taken place because psychiatrists themselves have led the way. It is sad that ... their place as pioneers has been usurped by planners and politicians. It is time for the specialty to emerge from its torpor, cease its self-flagellation, and take on the mantle of leadership again.

The implications for the College of the findings of this snapshot of its members views are clear and challenging. The decision by Council to concentrate on making a success of one Annual Meeting is a welcome first move, given the dreadfully low value placed on the current cluster of meetings psychiatrists are expected to attend. But the College must go further. In addition to ensuring the College's commitment at such an annual gathering to education, training and research, all endorsed and supported in this survey, it needs to give more attention to more fundamental political issues. Issues such as "the increasing emphasis on the efficacy and cost effectiveness of all clinical services" and "the strengths and weaknesses of the NHS", important and controversial as such matters are, are parochial in the context of more basic questions, Such as that raised in a Lancet editorial, of how to bridge "the schism between narrow neuroscientific and more embracing sociocultural approaches" (Anonymous, 1997), or the question, more regularly articulated on the other side of the Irish Sea, of how to avoid an insularity that can, like a sort of institutional channel fog, cut Belgrave Square off from the rest of the world, or the even more fundamental question again, of the Royal College's place in and commitment to global psychiatry itself. Depression, fourth in the world league of disabling diseases, will be second only to ischaemic heart disease by 2020 . Schizophrenia will affect almost 25 million people in poorer nations by 2000 , a $45 \%$ increase since 1985. In the words of a Lancet editorial, "What does modern western psychiatry, with its goal of a 'scientific psychopathology', have to offer people in developing countries?" (Anonymous, 1997). On the basis of this survey's findings, there is a need for the College to improve its support for psychiatrists and to provide a better public definition of what it is psychiatrists do, of where psychiatry is going and should be going and how that journey should shape and affect not just psychiatrists and their patients but medicine and society, national and international. But, as this survey implicitly reminds us, psychiatrists are the College and it is they who must engage in this debate. Where better to engage in it than at future Annual Meetings of the College?

\section{References}

BRTISH JOURNAL OF PSYCHIATRY (1964) The future of organisational psychiatry in Great Britain and Ireland. British Journal of Psychiatry, 110 (suppl.) 1-22.

ANONYMOUS (1985) Psychiatry - a discipline that has lost its way. Lancet, i. 731-732.

- (1997) The crisis in psychiatry. Lancet, $4,965$.

Anthony W. Clare, Medical Director, St. Patrick's Hospital, PO Box No. 136. James's Street, Dublin 8 